\title{
DINAMIKA POLITIK PENDIDIKAN \\ GURU AGAMA ISLAM PADA MASA ORDE LAMA
}

\author{
Heni Listiana \\ (Dosen STAI Taruna)
}

\begin{abstract}
Abstrak
Politik pendidikan guru agama Islam pada masa Orde lama tidak dapat dilepaskan dari perjuangan memasukkan materi agama di sekolah. Sudah sejak lama Pemerintah Belanda menjadikan pendidikan agama terpisah dari pendidikan sekolah, dengan asumsi pendidikan sekolah itu netral dari pendidikan agama. Pendidikan agama menjadi urusan pribadi masing-masing dan bukan menjadi bagian integral pada pendidikan sekolah. Pemisahan ini menjadikan perbedaan yang sengit antara kaum nasionalis dan umat Islam dalam memandang pendidikan agama. Kaum nasionalis memiliki kecenderungan sinis dan apatis terhadap kaum muslim. Demikian juga kaum muslim berusaha untuk menyelamatkan kepentingannya dalam kancah politik di Indonesia sebagai mayoritas. Tetapi menjadi hal yang menarik untuk dikaji adalah meskipun Kementerian agama lahir belakangan tetapi usaha yang dilakukan pasca kemerdekaan harus diakui sebagai upaya yang luar biasa dalam menyediakan pendidikan yang berkualitas bagi umat Islam, terbukti dengan penyelenggaraan pendidikan guru yang pernah dijalankan.
\end{abstract}

Kata Kunci: Politik Pendidikan, Guru Agama, dan Orde Lama 


\section{A. Pendahuluan}

Membicarakan politik pendidikan guru agama Islam di negeri ini cukup menarik. Mengingat keberadaannya tidak bisa dilepaskan dengan dinamika perpolitikan yang ada, termasuk politik pendidikan guru agama Islam pada masa orde lama. Politik pendidikan guru agama Islam pada masa Orde lama tidak dapat dilepaskan dari perjuangan memasukkan materi agama di sekolah. Sudah sejak lama Pemerintah Belanda menjadikan pendidikan agama terpisah dari pendidikan sekolah, dengan asumsi pendidikan sekolah itu netral dari pendidikan agama. Pendidikan agama menjadi urusan pribadi masing-masing dan bukan menjadi bagian integral pada pendidikan sekolah. Pemisahan ini menjadikan perbedaan yang sengit antara kaum nasionalis dan umat Islam dalam memandang pendidikan agama.

Kaum nasionalis memiliki kecenderungan sinis dan apatis terhadap kaum muslim. Demikian juga kaum muslim berusaha untuk menyelamatkan kepentingannya dalam kancah politik di Indonesia sebagai mayoritas. Tetapi menjadi hal yang menarik untuk dikaji adalah meskipun Kementerian agama lahir belakangan tetapi usaha yang dilakukan pasca kemerdekaan harus diakui sebagai upaya yang luar biasa dalam menyediakan pendidikan yang berkualitas bagi umat Islam, terbukti dengan penyelenggaraan pendidikan guru yang pernah dijalankan. Upaya membangun kesejajaran dengan Kementerian Pendidikan dalam mengelola lembaga pendidikan menjadi hal yang tidak dapat dielakkan. Untuk itu perlu dibahas tentang model pendidikan guru agama Islam pada masa orde lama sebagai bagian dari politik pendidikan masa orde lama dalam fokus kajian politik ketenagaan.

\section{B. Pendidikan pada Masa Orde Lama (1945-1966)}

Pada Periode ini kegiatan pendidikan di tanah air lebih mengarah kepada pemantapan nilai-nilai nasionalisme, identitas bangsa, dan pembangunan fondasi ideologis kehidupan berbangsa dan bernegara. Tujuan utama pendidikan pada masa ini adalah nation and character building dan kendali utama penyelenggaraan pendidikan nasional dipegang oleh tokoh-tokoh nasionalis. Mereka menguasai berbagai posisi penting di institusi pemerintahan dan secara aktif dan sistematis 
menjadikan pendidikan sebagai bagian integral dari proses sosialisasi ideologi negara dan penataan corak kehidupan berbangsa dan bernegara. ${ }^{1}$

Upaya untuk mewujudkan tujuan pendidikan pada masa ini dilakukan oleh Kementerian Pendidikan dan Kementerian Agama. Fokus utama Kementerian Agama adalah terselenggaranya Pendidikan Agama di seluruh Indonesia. Berbagai upaya dilakukan untuk mewujudkan pendidikan agama yang berkualitas. Dalam kerangka memberikan pedoman, dukungan dan jaminan kualitas (quality assurance) terhadap proses belajar mengajar di madrasah - termasuk pesantren - pada 1946, tidak lama setelah didirikan, Kementerian Agama membentuk divisi khusus untuk mengurus pendidikan agama. Divisi yang disebut Japenda (Jawatan Pendidikan Agama) memiliki mandat mengurus seluruh masalah yang berkaitan dengan pengembangan madrasah di seluruh Indonesia.

Sejalan dengan mandat yang diemban, Japenda memusatkan perhatian pada dua hal utama. Pertama, mendirikan sekolah-sekolah untuk mencetak guru agama Islam modern di sekolah-sekolah umum negeri, sejak proklamasi berada dibawah pembinaan Kementerian Pendidikan, merumuskan kurikulum dan menyiapkan buku-buku pelajaran Islam. Sekolah guru agama modern ini menjadi salah satu embrio bagi madrasah-madrasah modern di Kementerian Agama. Kedua, melakukan "modernisasi" madrasah dengan beberapa strategi, yaitu memperbarui kurikulum dan mainstreaming mata pelajaran umum di madrasah, mengembangkan kualitas dan kuantitas guru-guru bidang umum, menyediakan fasilitas belajar seperti buku-buku bidang studi umum dan mendirikan madrasah negeri sebagai percontohan atau model bagi lembaga pendidikan Islam setingkat. ${ }^{2}$

Guna merealisasikan mandat Japenda dalam mendirikan sekolahsekolah untuk menghasilkan guru agama Islam modern. Maka Japenda mendirikan Sekolah Guru dan Hakim Agama Islam (SGHAI) dan Sekolah Guru Agama Islam (SGAI). Gagasan itu lahir dari konsep

\footnotetext{
${ }^{1}$ Sirozi, Politik Pendidikan Dinamika Hubungan antara Kepentingan Kekuasaan dan Praktik Penyelenggaaraan Pendidikan (Jakarta: Raja Grafindo Persada, 2010), 188

2 Arief Subhan, Lembaga Pendidikan Islam Indonesia Abad ke-20 Pergumulan antara Modernisasi dan Identitas "(Jakarta: Kencana,2012),236-237
}

Jurnal Pendidikan Agama Islam

Volume 02 Nomor 02 November 2013

Hal $376-398$ 
Abdullah Sigit (1950-1952) dan Arifin Tameyang (1952-1958) yang melakukan ekspolasi konsep pendidikan guru agama dengan menggunakan pendekatan yang berbeda. Abdullah Sigit mengedepankan terwujudnya guru agama modern dengan menekankan pada ilmu umum, sementara Arifin Tameyang menekankan keseimbangan antara ilmu umum dan ilmu agama. Berbagai perubahan yang terjadi untuk menemukan model pendidikan guru agama Islam ideal dilakukan dalam merespon perkembangan dan kepentingan umat Islam. Perjalanan sekolah-sekolah itu menjadi bukti bahwa Kementerian Agama sangat konsen untuk melakukan perubahan pendidikan agama di Indonesia. Tarik ulur politik dan kepentingan untuk memperjuangkan terselenggaranya pendidikan agama menjadi bukti bahwa ada usaha besar untuk mewujudkan pendidikan agama yang berkualitas. Selain itu pendidikan agama juga menjadi bukti terakomodasinya kepentingan mayoritas muslim Indonesia.

\section{Kementerian Agama dan Pendidikan Guru Agama}

B.J Boland melukiskan keberadaan Kementerian Agama sebagai "unique phenomenon in our world". ${ }^{3}$ Diantara negara-negara dengan mayoritas penduduk muslim, tidak dijumpai kementerian serupa dengan mandat yang demikian besar sebagaimana Kementerian Agama di Indonesia. Bagi Boland, keberadaan Kementerian Agama dalam konteks negara Indonesia sebagai "jalan tengah" yang dapat ditempuh diantara ketegangan yang terjadi antara kelompok-kelompok masyarakat yang bercita-cita membentuk "negara sekuler" di satu sisi, dan kelompok masyarakat yang mencita-citakan "negara Islam" di sisi lain.

Dalam konteks pendidikan Islam, Kementerian Agama merupakan lembaga yang memiliki mandat untuk memberikan "giude, support and inspect education and teaching given in madrasahs. ${ }^{4}$ Dalam artikel berjudul "Assumptions Underlaying Religious Instruction in Indonesia", Lambert Kelabora memberikan penilaian kritis tentang pendidikan agama di sekolah umum. Dari perspektif sekuler, Kelabora

${ }^{3}$ B.J. Boland, The Struggel of Islam in Modern Indonesia,(The Hague: Martinus Nijhoff,1997), 105

${ }^{4}$ Arief Subhan, Lembaga Pendidikan Islam .....230 
berpendapat bahwa pendidikan agama di sekolah umum lebih didasarkan kepada asumsi-asumsi yang bersifat religious, ideologis, dan politis dengan mengabaikan argumentasi-argumentasi yang merujuk kepada konsepsi pendidikan sebagai institusi yang bersifat netral terhadap agama. Ia juga menguraikan bahwa sistem sentralisasi pendidikan di Indonesia di bangun berdasarkan berbagai kekhawatiran. Sebagai contoh, dalam konteks pendidikan, terdapat kekhawatiran seandainya anak-anak diizinkan mempelajari subyek yang dikehendaki, maka mereka akan menjadi pribadi-pribadi yang tidak dikehendaki, seandainya guru diberikan izin untuk mendesain kurikulum sendiri, maka lembaga pendidikan akan bersebrangan dengan kepentingan nasional; seandainya mata pelajaran agama tidak diajarkan maka mereka akan menjadi manusia yang tidak beragama. ${ }^{5}$

Guru merupakan elemen penting dalam penyelenggaraan mata pelajaran agama di sekolah. Guru yang dibutuhkan adalah mereka yang memiliki kompetensi dalam bidang yang diajarkan. Standar tentang kompetensi sepenuhya tergantung kepada kebijakan otoritas pendidikan. Disamping itu, guru juga harus memilki komitmen, dedikasi, pengetahuan keislaman yang memadai, kemampuan pedagogi, dan kemampuan meletakkan ajaran Islam dalam konteks modern. Sebagaimana disebutkan undang-undang, Kementerian Agama memliki mandat untuk menyiapkan guru agama, kurikulum, dan buku-buku teks pendidikan Islam di sekolah umum. Mengingat kompetensi guru yang dikehendaki menuntut kualifikasi tertentu, Kementerian Agama mendirikan sekolah guru. Sekolah-sekolah tersebut memiliki dua tujuan. Pertama, menyiapkan guru modern untuk pelajaran Islam di sekolah. Kedua, menyiapkan guru mata pelajaran umum di madrasah sebagai bagian dari proyek modernisasi madrasah. ${ }^{6}$

\footnotetext{
${ }^{5}$ Lambert Kelabora,Assumption Underlaying Religious Instruction”, 325-329

${ }^{6}$ D.P. Sati Alimin (ed). Almanak Djawatan Pendidikan Agama 1959, (Jakarta: N.Vperdana,1959), 67 


\section{Hubungan Kausalitas Pelajaran Agama dan Guru Agama di Sekolah}

Perjuangan memasukkan pelajaran agama di sekolah berjalan beriringan dengan kebutuhan guru yang berkualitas. Dengan keharusan mempelajari pelajaran agama maka harus tersedia guru agama yang dihasilkan oleh Kementerian Agama. Isu tentang mata pelajaran agama di sekolah merupakan isu yang muncul pada periode setelah penjajahan. Sekolah-sekolah Belanda memegang prinsip netralitas sehingga pendidikan agama tidak diberikan porsi didalamnya. Lembaga pendidikan tidak ikut campur terhadap urusan keyakinan atau agama seseorang karena dianggap sebagai urusan pribadi. Meskipun demikian, para pemimpin Islam menyangsikan netralitas tersebut karena mereka menjumpai kenyataan bahwa para lulusan sekolah-sekolah Belanda cenderung sinis, bahkan benci terhadap kalangan agama, khususnya agama Islam. Oleh karena itu, setelah kemerdekaan, mata pelajaran agama di sekolah mendapat penekanan dalam undang-undang.

Beberapa proses penting untuk memasukkan materi agama pada sekolah umum dapat dilihat dari perjalan sejarah sebagai berikut. Pertama, BP KNIP (Badan Pekerja Komite Nasional Indonesia Pusat), dalam rapatnya tanggal 27 Desember 1945, membuat sejumlah rekomendasi kepada Kementerian Pengajaran, Pendidikan dan Kebudayaan (PP dan K). Rekomendasi itu berisi tentang: "pengajaran agama hendaknya mendapat tempat yang teratur seksama, hingga cukup mendapat perhatian yang semestinya degan tidak mengurangi kebebasan golongan-golongan yang berkehendak mengikuti kepercayaan yang dipeluknya. Dalam hal ini, Kementerian mengadakan perundingan dengan BP KNIP"?

Kedua, sebagai respon atas rekomendasi BP KNIP, Menteri PP dan K (Mr. Soewandi), pada tanggal 1 Maret 1946, membentuk Panitia Penyelidik Pengajaran melalui Surat Keputusan Nomor 104/Bhg.O.1946)

7 Soegarda Poerbakawatja, Pendidikan dalam Alam Indonesia Merdeka (Jakarta: Gunung Agung,1970), 38 
yang dipimpin Ki Hajar Dewanta dan Soegarda Poerbakawatja sebagai sekretaris, ${ }^{8}$ dengan tugas:

1. Merencanakan susunan baru dari tiap-tiap macam sekolah (schootype);

2. Menetapkan bahan-bahan pengajaran dengan menimbang keperluan yang praktis dan jangan terlalu berat (overladen);

3. Menyiapkan rencan-rencana pelajaran untuk tiap-tiap sekolah dan tiap-tiap kelas (fakultas juga) disertai dengan daftar-daftar dan keterangan-keterangan yang lengkap $;^{9}$

Dalam laporan yang disusun tanggal 2 Juli 1946, Panitia Penyelidik berhasil merumuskan sejumlah hal penting tentang pendidikan agama, Panitia Penyelidik merekomendasikan hal-hal berikut:

1. Pelajaran agama dalam semua sekolah diberikan pada jam pelajaran sekolah;

2. Para guru dibayar oleh pemerintah;

3. Pada sekolah dasar, pendidikan agama diberikan mulai kelas IV;

4. Pendidikan ini diselenggarakan seminggu sekali pada jam tertentu;

5. Para guru agama diangkat oleh Kementerian Agama;

6. Para guru agama diharuskan juga cakap dalam pendidikan umum;

7. Pemerintah menyediakan buku untuk pendidikan agama;

8. Diadakan latihan bagi para guru agama;

9. Kualitas pesantren dan madrasah harus diperbaiki; dan

10.Pengajaran bahasa Arab tidak dibutuhkan. ${ }^{10}$

Ketiga, menindaklanjuti rekomendasi di atas, Menteri Agama (K.H.R. Fathurrahman Kafrawi) dan Menteri PP dan K (Mr. Soewandi) membuat kesepakatan bersama tentang pendidikan agama disekolah dalam bentuk Peraturan Bersama Menteri PP dan K dan Menteri Agama Nomor 1142/BHG.A (pengajaran) pada tanggal 2 Desember 1946 dan

\footnotetext{
${ }^{8}$ Mujahid AK dan Achmad Syahid,ed. Memelihara Tradisi Merayakan Inovasi 25 Tahun Puslitbang Pendidikan Agama dan Keagamaan (Jakarta: Badan Litbang Agama dan Diklat Keagamaan Departemen Agama RI, 2003), 15

9 Soegarda Poerbakawatja, Pendidikan dalam Alam ...37

${ }^{10}$ Karel A. Steenbrink,Pesantren Madrasah Sekolah;Pendidikan Islam dalam Kurun Moderen (Jakarta: LP3ES), 91; dari 10 rekomendasi tersebut, yang berhubungan dengan pendidikan agama di sekolah adalah nomor 1-8. Sementara nomor 9 dan 10 terkait dengan madrasah dan pesantren.
}

Jurnal Pendidikan Agama Islam

Volume 02 Nomor 02 November 2013

Hal $380-398$ 
Nomor 1285/KJ9 (Agama) tertanggal 12 Desember 1946. Isi peraturan bersama tersebut, antara lain, menyebutkan: "Pendidikan agama disekolah-sekolah rendah diberikan sejak kelas IV dan berlaku mulai 1 Januari 1947"." Peraturan ini adalah landasan hukum pertama dari pendidikan agama di sekolah-sekolah negeri oleh pemerintah, sekaligus sebagai bentuk akomodasi legislatif ${ }^{12}$ pertama bagi umat Islam dalam bidang pendidikan agama di lembaga pemerintah. Dalam perkembangannya, peraturan bersama tersebut disempurnakan melalui Peraturan Bersama Menteri PP dan K dan Menteri Agama No.1432/Kab, 20 Januari 1951 (Pendidikan), dan No.KI/652, 20 Januari 1951 (Agama) tentang peraturan Pendidikan Agama di sekolah-sekolah. Selanjutnya, peraturan ini disempurnakan kembali melalui Peraturan Bersama Menteri PP dan K dan Menteri Agama No.17678/Kab, 16 Juli 1951 (Pendidikan), dan No. KI/9180, 16 Juli 1951 (Agama) tentang Peraturan Pendidikan Agama di sekolah-sekolah.

Ketetapan pendidikan agama sebagai salah satu mata pelajaran di sekolah umum menjadi tantangan tersendiri bagi Kementerian Agama karena-sebagimana bunyi rekomendasi tersebut-guru agama harus disiapkan oleh Kementerian Agama. Tugas ini merupakan beban yang tidak ringan mengingat Kementerian ini baru berdiri, pada masa itu guruguru agama pada umumnya hanya ahli dalam bidang studi agama. ${ }^{13}$ Padahal yang dikehendaki pemerintah adalah guru agama yang memahami pengetahuan umum. Oleh karena itu untuk menindaklanjuti rekomendasi di atas, Kementerian Agama sejak 1 Januari 1947 telah merancang pengadaan guru agama melalui sejumlah program, yaitu: ${ }^{14}$

1. Pengadaan guru agama secara kilat melalui pelatihan selama dua minggu. Melalui cara ini, dari 90 orang yang dilatih, hanya 45 orang yang lulus.

11 Marwan Saridjo, Bunga Rampai Pendidikan Agama Islam (Jakarta: Amisco,1996), 56; dan Haidar Putra Daulay, Historisitas dan Eksistensi Pesantern Sekolah dan Madrasah (Yogyakarta: Tiara Wacana, 2001), 53

12 Bachtiar Effendy,Islam dan Negara: Transformasi Pemikiran dan Praktik Politik Islam di Indonesia (Jakarta: Paramadina, 1998), 278-302.

${ }^{13}$ Guru agama yang ada pada saat itu umumnya merupakan hasil didikan pesantren dan sekolah-sekolah guru agama yang diprakarsai umat Islam.

14 Almanak 1974 (Jakarta: Direktorat Pendidikan Agama Dirjen Bimas Islam Departemen Agama,t.th), 72, Rahim, Arah Baru Pendidikan Islam, 59-60. 
2. Pengadaan guru agama secara cepat melalui sistem pemeriksaan bertingkat, yakni pemeriksaan awal di daerah dan pemeriksaan akhir di pusat.

3. Pengadaan guru agama jangka pendek melalui program pendirian sekolah guru agama 2 tahun bagi lulusan SMP dan MTs. ${ }^{15}$

4. Pengadaan guru agama jangka panjang melalui program pendirian sekolah guru agama 5 tahun bagi lulusan SD dan MI. ${ }^{16}$

Empat tahun sebelum undang-undang No.4 Tahun 1950 ditetapkan, Menteri Agama telah menandatangani kesepakatan dengan Menteri Pendidikan dalam bentuk "Penetapan Bersama" yang berisi jumlah jam pendidikan agama di sekolah. Disepakati bahwa pendidikan agama diselenggarakan di sekolah mulai kelas 4 Sekolah Rendah (SR) (setingkat SD sekarang). Adapun untuk kelas 1,2, dan 3, pendidikan agama tidak diberikan. Kesepakatan yang dibuat saat pemerintah Indonesia berkedudukan di Yogyakarta itu menunjukkan bahwa sejak semula kelompok Islam di Indoensia menghendaki agar pendidikan agama diberikan di sekolah. Aspirasi inilah yang kemudian diperjuangkan dalam penyusunan undang-undang pendidikan. Pada tahun 1951, setahun setelah undang-undang pendidikan disahkan, kedua kementerian itu kembali membuat "Peraturan Bersama". ${ }^{17}$

“.....di lingkungan jang istimewa pendidikan Agama dapat dimulai dikelas 1 dan djamnya dapat ditambah menurut kebutuhan tetapi tidak melebihi 4 djam seminggu dengan ketentuan bahwa mutu pengetahuan bagi sekolah rendah itu tidak

15 Istilah SMP dipakai mulai tahun 1949, sebelumnya bernama SMLUP (Sekolah Menengah Lanjutan Umum Pertama). Sementara istilah Madrasah Tsanawiyah (MTs) digunakan mulai tahun 1978, sebelumnya Madrasah Lanjutan Tingkat Pertama (MLTP/1952), Madrasah Tsanawiyah Agama Islam/MTs.AI (1967). Sejak 1978 hingga kini menggunakan MTs.

${ }^{16}$ Istilah SR dipakai mulai tahun 1945-1950, setelah itu diganti SD hingga kini, Sementara MI digunakan sejak 1962, sebelumnya Madrasah Rendah (1952) dan sekolah rakyat Islam (1959).

${ }^{17}$ Peraturan Bersama bernomor Menteri Agama No.K/I/9180 tanggal 16 Juli 1951 dan Meneteri Pendidikan No. 17678/Kab. Tanggal 16 Juli 1951. DP. Sati Alimin (ed), Almanak Djawatan Pendidikan Agama,37

Jurnal Pendidikan Agama Islam

Volume 02 Nomor 02 November 2013

Hal $382-398$ 
boleh dikurangi dibandingkan dengan sekolah rendah di lain lingkungan" (pasal 2). ${ }^{18}$

Posisi mata pelajaran agama merupakan bagian dari perjuangan kaum muslim pada periode awal kemerdekaan sampai pada periode kontemporer, dan menjadi landasan bagi Kementerian Agama dalam mendirikan sekolah-sekolah guru agama Islam modern. Menurut Dokumentasi yang tersedia, pada 1957 kebutuhan terhadap guru agama tercatat cukup besar.

Daftar kebutuhan guru agama pada tahun $1957^{19}$

\begin{tabular}{|l|c|}
\hline Sekolah Rendah & 12.260 orang \\
\hline Sekolah Menengah & 1.600 orang \\
\hline Sekolah Menengah Atas & 420 orang \\
\hline Jumlah guru & 14.280 orang \\
\hline Guru yang tersedia & 9.629 guru \\
\hline
\end{tabular}

Untuk memenuhi kebutuhan ini, pada tahun 1950-an Japenda Kementerian Agama membuat langkah terobosan-yang dapat dikatakan sebagai langkah darurat-dengan menyelenggarakan "Ujian Guru Agama" (UGA) sebagai jalan untuk merekrut guru secara cepat. Komitmen terhadap keislaman merupakan persyaratan utama dalam ujian tersebut. ${ }^{20}$

${ }^{18}$ D.P. Sati Alimin (ed). Almanak Djawatan....38

${ }^{19}$ D.P. Sati Alimin (ed). Almanak Djawatan....141

${ }^{20}$ Program UGA dilakukan dua kali, Pertama, pada tahun 1950 sampai dengan 1954. Kedua, pada 1967-setelah peristiwa G-30 S/PKI 1965. Guru agama yang direkrut melalui jalur UGA mendapat kritik antara lain,"kurang pengetahuan umum dan tidak menguasai didaktikmetodik". Sampai dengan 1970 jumlah guru agama jalur UGA sebanyak 58.856 orang. Husni Rahim, Madrasah dalam Politik Pendidikan di Indonesia, (Jakarta: Logos,2005),148-149. 
Heni Listiana

\section{E. Beberapa Model Sekolah Guru Agama yang Diselenggarakan Kementerian Agama Masa Orde Lama}

\section{Sekolah Guru dan Hakim Agama Islam (SGHAI) 1946-1950}

Pengadaan guru agama melalui pendirian sekolah diawali dengan pendirian Sekolah Guru dan Hakim Agama Islam (SGHAI) ${ }^{21}$ di Solo pada tanggal 16 Mei 1948. Informasi yang pasti tentang alasan Kementerian Agama memilih Solo sebagai tempat pendirian SGHAI, belum ditemukan. Yang jelas, letak Solo berdekatan dengan Yogyakarta, ibukota RI ketika itu ${ }^{22}$, dan Solo sejak Awal dikenal sebagai salah satu basis pergerakan Islam. Sarikat Dagang Islam (SDI) berdiri tahun 1911 di Solo. Di wilayah ini pula, pada tahun 1939, berdiri perguruan tinggi Islam. Karena terjadi Agresi Militer Belanda II (19 Desember 1948), SGHAI yang baru beberapa hari pindah ke Yogyakarta terpaksa ditutup. ${ }^{23}$

Setelah situasi kembali kondusif, terutama pasca pengakuan kedaulatan RI oleh Belanda, SGHAI di buka kembali tanggal 16 Januari 1950 di Yogyakarta berdasarkan Peraturan Menteri Agama Nomor 3/C-3/1950 (3 Januari 1950), dengan menerima peserta didik berikatan dinas ${ }^{24}$. Dengan status ikatan dinas, selama mengikuti pendidikan, para murid mendapat tunjangan ikatan dinas dari

\footnotetext{
${ }^{21}$ Beberapa sumber mamakai nama SGHI, bukan SGHAI, yang merujuk kepada Mahmud Yunus (SGHAI) karena yang bersangkuta termasuk pelaku sejarah ketika itu.

${ }^{22}$ Yogyakarta menjadi ibu kota RI sejak tanggal 4 Januari 1946. Sebagaimana dimaklumi, pasca kemerdekaan RI 17 Agustus 1945, tentara sekutu (Inggris) datang kembanli ke Indonesia pada akhir September 1945. Kedatangan mereka diboncengi tentara NICA- bentukan Belanda-dan tentara Belanda yang ingin menguasai RI kembali. Maka terjadilah pertempuran terus menerus antara RI melawan Sekutu/Belanda. Dalam pertemouran tersebut, banak lokasi penting dikuasai sekutu. Jakarta, ibukota RI, menjadi target utama. Gedung-gedug di Jakarta dikuasai sekutu sehingga situasi kota menjad tidak aman. Akhirnya, ibukota RI pindah ke Yogyakarta yang relati aman pada tanggal 4 Januari 1946.

23 Azyumardi Azra, HM Rasjidi BA Pembentukan Kementerian Agama dalam Revolusi, dalam Azyumardi Azra dan Saiful Umam, ed. Menteri-menteri Agama RI Biografi Sosial Politik,(Jakarta:INIS,1998),8-10.

${ }^{24}$ Amal Bakti Departemen Agama RI 3 Januari 1946-3 Januari 1996 (50 Tahun Departemen Agama);Eksistensi\&Derap Langkahnya (Jakarta:Departemen Agama RI,1996),33
}

Jurnal Pendidikan Agama Islam

Volume 02 Nomor 02 November 2013

Hal 384 - 398 
pemerintah. Setelah lulus, mereka langsung bertgas sebagai guru agama dengan status PNS. Kebijakan ikatan dinas ini hanya berlangsung sampai $1969 .{ }^{25}$ Setelah itu, karena keterbatasan anggaran Kementerian Agama, murid di lembaga pendidikan guru agama harus membiayai sendiri pendidikannya, dan lulusannya pun tidak otomatis di angkat mejadi guru PNS.

\section{Masa SGHAI-SGAI/SGHA-PGA (1950-1953)}

Pemerintah mengesahkan Undang-undang No.4/1950 tentang Dasar-dasar Pendidikan dan Pengajaran di Sekolah pada 2 April $1950 .{ }^{26}$ Undang-undang ini, antara lain, mengatur program wajib belajar dan pengajaran agama di sekolah, seperti termuat dalam pasal berikut:

a. Pasal 10 ayat (1) "Semua anak-anak yang sudah berumur 6 tahun berhak dan yang sudah berumur 8 tahun diwajibkan belajar di sekolah, sedikitnya 6 tahun lamanya". Ayat (2)"Belajar di sekolah agama yang telah mendapat pengakuan dari Menteri Agama dianggap telah mendapat pengakuan dari Menteri Agama dianggap telah memenuhi kewajiban belajar".

b. Pasal 20 ayat (1) "Dalam sekolah-sekolah negeri diadakan pelajaran agama, orang tua murid menetapkan apakah anaknya akan mengikuti pelajaran tersebut; ayat (2) " Cara menyelenggarakan pelajaran agama di sekolah-sekolah negeri diatur dalam peraturan yang ditetapkan oleh Menteri Pendidikan, Pengajaran dan Kebudayaan bersama-sama Menteri Agama."

Pasal khusus tentang pendidikan agama, seperti termuat pada pasal 10 tersebut, kian meneguhkan kedudukan pendidikan agama di sekolah, dari yang semula hanya berdasar surat keputusan bersama menteri, kemudian dikuatkan dalam bentuk undang-undang.

\footnotetext{
${ }^{25}$ Zaini Ahmad Syis, Inventarisasi dan Pengefektifan Out put PGAN sehubungan dengan Pengadaan Guru Agama Tingkat Dasar”, dalam laporan Lokakarya Out put PGAN bagi Angkatan Kerja (Jakarta: Pusat Penelitian dan Pengembangan Pendidikan Agama Badan Litbang Departemen Agama,1978/1979),50-56

${ }^{26}$ Muljanto Sumardi, Sejarah Singkat Pendidikan Islam di Indonesia 1945-1975 (Jakarta:Lembaga Penelitian Ilmu Agama),dan Kemasyarakatan (LPIAK)-Badan Penelitian dan Pengembangan Agama Departemen Agama,1977),66
} 
Pengakuan sekolah agama (madrasah) sebagai bagian dari penyelenggara program wajib belajar, juga menunjukkan bahwa keberadaan madrasah mulai diakui dalam sistem pendidikan nasional.

Untuk pelaksanaan amanat undang-undang tersebut, terutama dalam hal penyelenggaraan program wajib belajar dan pendidikan agama di sekolah, pendirian sekolah baru semakin ditingkatkan. Pertambahan jumlah sekolah berimplikasi pada bertambahnya kebutuhan guru. Maka, untuk memenuhi kebutuhan tersebut pada tanggal 15 Agustus 1950 Kepala Jawatan Pendidikan Agama [Abdullah Sigit] mengeluarkan Surat Edaran Nomor 277/C/C-9 yang menganjurkan perluasan SGHAI (Sekolah Guru dan Hakim Agama Islam) dan pendirian SGAI (Sekolah Guru Agama Islam).

Meskipun kedua lembaga tersebut adalah sekolah guru, namun keduanya memiliki tujuan berbeda. Lulusan SGHAI disiapkan menjadi guru di madrasah ibtidaiyah, untuk guru mata pelajaran agama dan mata pelajaran umum, sementara lulusan SGAI diarahkan menjadi guru agama di sekolah dasar. Perbedaan lain dari kedua lembaga ini adalah:

a. Masa studi SGHAI adalah empat tahun setelah lulus MTs atau SMP. Lembaga ini memiliki empat bagian/program, yaitu: (a) Bagian A untuk calon guru kesusastraan; (b) Bagian B untuk calon guru ilmu alam; (c) Bagian C untuk calon guru agama; dan (d) Bagian D untuk calon pegawai pada pengadilan agama;

b. SGAI, terdiri dari dua program, jangka pendek dan jangka panjang: (a) Program jangka pendek, lama belajarnya dua tahun setelah MTs atau SMP. Karena itu, program jangka pendek ini disebut SGAI 2 tahun; (b) Program jangka panjang, masa belajarnya lima tahun setelah SD 6 tahun atau MI 6 tahun. Program jangka panjang ini disebut SGAI 5 tahun.

Pada mulanya SGHAI-SGAI hanya didirikan di pulau Jawa. Setelah Indonesia kembali menjadi Negara Kesatuan Republik Indonesia (17 Agustus 1950), Menteri Agama bermaksud membuka kedua lembaga tersebut di seluruh Indonesia. Dengan didasari Penetapan Menteri Agama (KH. Wahid Hasyim) Nomor 7/1951 (tanggal 15 Pebruari 1951), Kementerian Agama memutuskan untuk 
memperluas pendirian kedua lembaga pendidikan guru tersebut dengan sedikit perubahan, yaitu:

a. Nama SGHAI di ganti menjadi SGHA (Sekolah Guru dan Hakim Agama) dengan masa belajar tetap 4 tahun setelah MTs/SMP.

b. Nama SGAI diganti menjadi PGA (pendidikan Guru Agama) dengn lama belajar 5 tahun (setelah MI/SD). ${ }^{27}$

Atas dasar kebijakan tersebut, perluasan institusi terus diupayakan. Sampai akhir tahun 1951, kedua lembaga tersebut telah menyebar ke beberapa wilayah karesidenan hingga mencapai jumlah 25 lembaga dan terdiri dari 5 SGHA dan 20 PGA, dengan rincian sebagai berikut:

a. Lima SGHA dibuka di Yogyakarta Bagian A, B, D), Malang (Bagian A,B) Kotaraja Banda Aceh (Bagian C), Bukit Tinggi (Bagian C) dan Bandung (Bagian A,B,C).

b. Dua puluh PGA di buka di Tanjung Pinang, Kotaraja Banda Aceh, Padang, Banjarmasin, Jakarta, Tanjung Karang, Bandung, Pamekasan, Bogor, Cirebon, Purwokerto, Pekalongan, Magelang, Solo, Salatiga, Kudus, Madiun, Bojonegoro, Kediri dan Jember.

Konsep SGHAI-SGAI disebut dengan "Rencana Sigit", ${ }^{28}$ Karena konsep tersebut digagas dimasa Abdullah Sigit menjabat sebagai Kepala Jawatan Pendidikan Agama. Kelebihan "Rencana Sigit" ini terletak pada pendirian SGHA. Dengan berdirinya lembaga ini, lulusan MTs dapat melanjutkan pendidikannya ke jenjang yang lebih tinggi melalui SGHA (Khususnya bagian C dan D) yang selama masa penjajahan Hindia Belanda peluang tersebut tertutup. Sebelumnya memang ada sambungan bagai lulusan MTs seperti Normal Islam, Islamic College, Kulliah Muballighin/Muballighat, dan sejenisnya. Namun lembaga-lembaga tersebut sebagian telah ditutup. Dengan berdirinya SGHA, lulusan MTs memiliki peluang lebih luas untuk melanjutkan pendidikannya. Kelebihan lain dari SGHA, guru agama lulusan lembaga ini kualitasnya lebih baik dibanding lulusan

${ }^{27}$ Mahmud Yunus, Sejarah Pendidikan Islam (Jakarta:Mutiara,1992), 360-361

${ }^{28}$ Mahmud Yunus, Sejarah Pendidikan Islam, 362 
Heni Listiana

PGA karena mereka telah terdidik dalam ilmu agama Islam beberapa tahun lamanya sebelum masuk SGHA, yaitu di MI dan MTs.

Kelemahan "Rencana Sigit" terletak pada PGA. Lulusan lembaga ini ternyata kurang mampu menjadi guru agama. Kurikulum PGA 5 tahun yang setara dengan SG B 4 (Sekolah Guru B 4 tahun) tahun ditambah materi agama dan bahasa arab. Dengan kurikulum ini, lulusan PGA belum matang menjadi guru agama, bahkan mereka lebih siap menjadi guru umum karena kurikulumnya didominasi pelajaran umum seperti pelajaran yang diterima murid SG B.

Kurikulum PGA menggunakan standar SG B Plus, Tampaknya Sigit hendak mengangkat citra guru agama di sekolah. Sebelumnya guru agama di pandang sebelah mata oleh pihak sekolah karena mementingkan ilmu agama dan mengabaikan pelajaran umum. Dengan pandangan demikian, guru-guru agama di sekolah merasa rendah diri. Karena itu, dengan menggunakan standar kurikulum SGB calon guru agama di sekolah umum diharapkan tidak merasa rendah diri dan tidak diremehkan guru-guru umum di sekolah. Di samping itu, calon guru agama sekolah umum diharapkan memiliki wawasan luas dengan mengajarkan agama dengan standar SGB.

Konsep Sigit yang cenderung menekankan materi umum ini awalnya ditentang KH. Imam Zarkasyi, sejawatnya di Kementerian Agama ketika itu. Zarkasyi mengusulkan agar kurikulum yang dikembangkan lebih mengarah pada penguatan pendidikan agama tanpa meninggalkan pendidikan umum. Dari dua konsep tersebut, Menteri Agama-yang ketika itu dijabat KH. Faqih Usman-lebih berpihak pada Sigit. Akhirnya, Konsep Sigit yang dipakai. ${ }^{29}$

\section{Masa PGA 6 Tahun (1953-1978)}

Dalam perkembangan berikutnya, pergantian pejabat di lingkungan Japenda berdampak pada perubahan sistem pendidikan guru. Setelah jabatan Kepala Japenda beralih dari Abdullah Sigit (1950-1952) ke Arifin Temyang (1952-1958), "Rencana Sigit" yang baru berjalan dua tahun diganti dengan "Rencana Arifin". Dalam

29 K.H. Imam Zarkasyi, Peletak Modernisasi Pendidikan Pesantren, Madrasah; Jurnal Komunikasi Dunia Perguruan Tinggi (No.03/I/April-Juni 1997), 42-43

Jurnal Pendidikan Agama Islam

Volume 02 Nomor 02 November 2013

Hal 388 - 398 
rencana baru ini, terdapat perubahan kebijakan dalam penyelenggaraan pendidikan guru, yaitu:

a. Mengganti PGA 5 tahun menjadi PGA 6 tahun, yang terdiri dari PGA Pertama 4 tahun (kelas 1 sampai IV) dan PGA Atas 2 tahun (Kelas V sampai VI). Perubahan kebijakan ini didasarkan Penetapan Menteri Agama Nomor 35/1953 tertanggal 21 Nopember 1953.

b. Menghapus keberadaan SGHA bagian A, B dan C. Sementara bagian $\mathrm{D}$, karena masih dibutuhkan, diganti dengan lembaga baru yang secara khusus mendidik calon pegawai pengadilan agama, bernama PHIN (Pendidikan Hakim Islam Negeri). Penghapusan SGHA didasarkan pada Penetapan Menteri Agama teanggal 19 Mei 1954 Nomor 14/1954, terhitung mulai tanggal 1 Juni 1954.

Perubahan masa belajar PGA masa belajar PGA dari 5 tahun menjadi 6 tahun didasari hasil evaluasi bahwa lulusan PGA 5 tahun belum cukup matang menjadi guru agama karena alokasi waktu materi agama sangat terbatas. Karena itu, untuk meningkatkan kemampuan agama mereka, masa belajarnya perlu ditambah menjadi dua tahun.

Standar kurikulum PGA 6 tahun tetap setara dengan urikulum SGB 4 tahun, ditambah dua tahun untuk memperdalam pelajaran agama dan bahasa Arab. Kurikulum PGA 6 tahun terdiri dari dua bagian, bagian pertama dari kelas I sampai IV, dan bagian aas dari kelas V sampai kelas VI dengan ketentuan: (a) Kelas i dan II adaah bagian tempat untuk mempersamakan tingkat pengetahuan murid yang berasal dari SD 6 tahun dan MI 6 tahun, dengan pelajaran ilmu agama sebanyak seperempat dari seluruh jumlah jam pelajaran yang diberikan; (b) kelas III dan IV, selain berisi ilmu pengetahuan umum yang sama dengan SMP bagian A, diberikan juga ilmu agama sebanyak sepertiga dari seluruh jumlah jam pelajaran yang diberikan; (c) bagian atas (kelas V-VI), khusus untuk materi pendidikan keguruan, penyempurnaan ilmu pengetahuan umum dan ilmu pendidikan, serta memperbanyak ilmu agama menjadi sepertiga dari seluruh jumlah jam pelajaran yang diberikan. Murid yang lulus sampai kelas IV diberi penghargaan setara dengan lulusan SMP, sementara yang lulus sampai kelas VI mendapat Ijazah setaraa dengan 
tamatan sekolah-sekolah kejuruan lain yang diseleggarakan pemerintah yang lama belajarnya 6 tahun setelah SD/MI 6 tahun.

Kelemahan "Rencana Arifin" adalah penutupan SGHA (terutama bagian A, B, dan C). Setelah SGHA di tutup, calon guru agama di sekolah dasar dan madrasah disiapkan dalam satu wadah (PGA). Hal ini berbeda dengan "Rencana Sigit" yang disiapkan berbeda, calon guru agama di sekolah dasar disiapkan melalui PGA, semenara calon guru agama madrasah disiapkan melalui SGHA bagian C. Penghapusan SGHA bagian A dan B telah menutup peluang untuk menyiapkan calon guru mata pelajaran umum di madrasah. Padahal kebutuhan guru-guru umum di madrasah sangat penting seiring kian bertambahnya porsi pelajaran umum di madrasah. Disamping itu, pentingnya lulusan SGHA bagian A dan B bagi madrasah karena mereka diharapkan memiliki kemampuan untuk menyampaikan materi pelajaran umum berbasis Islam.

Dengan berlakunya "Rencana Arifin", banyak pihak yang kecewa. Di madrasah kebutuhan guru-guru umum di madrasah sangat penting seiring kian bertambahnya porsi pelajaran umum di madrasah. Disamping itu, pentingnya lulusan SGHA bagian A dan B bagi madrasah karena mereka diharapkan memiliki kemampuan untuk menyampaikan materi pelajaran umum berbasis Islam. Perubahan konsep tersebut telah menutup pintu bagi lulusan MTs untuk melanjutkan ke sekolah-sekolah Kementerian Agama. Demikian pula guru-guru mata pelajaran umum tidak bisa lagi diharapkan melalui lembaga pendidikan agama. Bahkan perubahan yang dilakukan Arifin cenderung mengurangi eksistensi sekolah keguruan di lingkungan Kementerian Agama. Terlepas dari alasan-alasan ini, kedua figur tersebut tentu saja telah turut berperan dalam modernisasi pendidikan Islam di Indonesia.

Sebagai dampak perubahan dan penataan institusi melalui "Rencana Arifin", lembaga pendidikan guru kian bertambah, dari yang semula berjumlah 25 menjadi 29 lembaga pada tahun 1954, dengan rincian PGAPN 20 lembaga dan PGAAN sebanyak 9 lembaga. Tiga tahun berikutnya, pada tahun 1957, jumlah PGAN meningkat signifika menjadi 47 lembaga, terdiri dari 31 PGAPN dan PGAAN. 
Jumlah pendidikan guru ini meningkat pesat, terutama setelah pemerintah pada tanggal 12 Maret 1954 mengeluarkan UU Nomor 14/1954 tentang Pernyataan Berlakunya UU Nomor 12/1950 tentang dasar-dasar Pendidikan dan Pengajaran di Sekolah. Untuk merespon undang-undang tersebut, terutama terkait dengan program wajib belajar dan pengajaran agama di sekolah, pendirian sekolah/madrasah semakin meluas dan sebagai akibatnya kebutuhan guru agama kian meningkat. Penambahan atau pendirian sekolah guru agama juga terus dilakukan.

Perubahan institusi sejak masa sigit hingga masa Arifn menyebabkan keberadaan lembaga pendidikan guru cukup beragam yaitu PGAPN 4 tahun, PGAAN 4 tahun, PGALN, PGAAN putri. Keragaan ini bisa jadi menyulitkan masyrakat mengenal lebih jauh keberadaan lembaga pendidikan guru agama. Disamping itu, pemerintah bisa menghadapi kesulitan administratif dalam penataan lebih lanjut lembaga-lembaga tersebut. Karena itu, Kementerian Agama mengupayakan penyederhanaan institusi melalui Penetapan Menteri Agama Nomor 18/1959 (29 April1959) tentang nama-nama sekolah Dinas Pendidikan Guru Agama, dengan ketentuan sebagai berikut:

a. Pendidikan guru Agama Pertama Negeri 4 tahun (PGAPN 4 tahun) diganti Pendidikan Guru Agama Negeri 4 tahun (PGAN 4 tahun), yaitu sekolah dinas yang menyelenggarakan bagian pertama dari pendidikan guru agama (kelas I sampai kelas IV). Lulusan PGAN 4 tahun ini bisa melanjutkan langsung ke kelas lima PGAN 6 tahun. Yang berhak diangkat menjadi guru agama adalah lulusan PGAN 6 tahun.

b. Pendidikan Guru Agama Atas Negeri 2 tahun (PGAAN 2 tahun) diganti Pendidikan Guru Agama Negeri 6 tahun (PGAN 6 tahun), yaitu sekolah dinas yang menyelenggarakan secara lengkap pendidikan guru agama mulai dari kelas I sampai kelas VI.

c. Pendidikan Guru Agama Atas Negeri Putri 2 tahun (PGAAN Putri 2 tahun) diganti Pendidikan Guru Agama Negeri Putri (PGAN Putri), yaitu sekolah dinas yang menyelenggarakan bagian atas 
(kelas V sampai kelas VI) dari pendidikan guru agama khusus putri. ${ }^{30}$

Keragaman jenis pendidikan guru terebut juga memerlukan peraturan lebih lanjut tentang tugas dan wewenang bagi lulusannya, karena dalam beberapa kasus, lulusan sekolah guru tersebut bertugas di luar wewenangnya. Misalnya, lulusan PGA 5 tahun mengajar di SMP, lulusan PGA 4 tahun bertugas sebagai guru sekolah dasar. Oleh karena itu, pada tanggal 28 Januari 1960, Peraturan Menteri Agama Nomor 10/1960 dikeluarkan untuk mengatur kedudukan dan wewenang para lulusan sekolah dinas guru pendidikan agama, dengan ketentuan sebagai berikut:

a. Lulusan PGA 5 tahun berwenang menjadi guru agama Islam di Sekolah Rakyat Negeri dan yang sederajat atau sebagai guru umum pada perguruan agama tingkat rendah, dalam lingkungan Kementerian Agama, sederajat dengan lulusan SGB Negeri.

b. Lulusan PGAPN/PGAN 4 tahun berwenang sebagai pegawai di lingkungan Kementerian Agama, sederajat dengan lulusan SLTP Negeri.

c. Lulusan PGAAN/PGALN/PGAN 6 tahun berwenang mengajar seperti tamatan PGA 5 tahun, dan dalam lingkungan Kementerian Agama serajat dengan SGA Negeri. Dalam keadaan darurat setelah mencukupi syarat-syarat kecakapan dan masa kerja tertentu, dapat dipekerjakan sebagai guru agama pada SLTP atau sebagai guru agama pengajar mata pelajaran umum pada perguruan agama Islam tingkat lanjutan pertama, dengan diberikan kedudukan sebagai guru agama pada SLTP.

d. Lulusan SGHA bagian A dan B berwenang menjadi guru agama pengajar mata pelajaran agama/umum pada sekolah Dinas Kementerian Agama atau perguruan agama Islam tingkat lanjutan pertama. Bagian $\mathrm{C}$ berwenang menjadi guru agama pengajar mata pelajaran agama pada sekolah negeri, sekolah dinas kementerian Agama dan perguruan agama Islam tingkat lanjutan pertama bagian $\mathrm{C}$, dalam kondisi darurat, setelah mencukupi syarat-syarat

${ }^{30}$ Muhammad Kosim, Pendidikan Guru Agama di Indonesia Pergumulan dan Problema Kebijakan 1948-2011 (Pustaka Nusantara, 2012), 37

Jurnal Pendidikan Agama Islam

Volume 02 Nomor 02 November 2013

Hal $392-398$ 
kecakapan dan masa kerja tertentu, dapat dipekerjakan sebagai guru agama pada sekolah lanjutan tingkat atas negeri dengan kedudukan sebagai guru agama pada SLTA.

\section{Perubahan Lembaga Pendidikan Guru Agama Islam Negeri Jenjang} Pendidikan Menengah

\begin{tabular}{|c|c|c|c|}
\hline No & Tahun & Nama Lembaga & Dasar Pendidikan/Perubahan \\
\hline 1 & $\begin{array}{l}1948- \\
1950\end{array}$ & SGHAI & $\begin{array}{l}\text { Peraturan Menteri Agama Nomor } \\
\text { 3/C-3/1950 }\end{array}$ \\
\hline 2 & 1950 & $\begin{array}{l}\text { SGHAI } 4 \text { tahun } \\
\text { SGAI } 2 \text { tahun } \\
\text { SGAI } 5 \text { tahun }\end{array}$ & $\begin{array}{l}\text { SE Kepala Bagian C (Pendidikan } \\
\text { Agama) Nomor 277/C.C-9/1950 }\end{array}$ \\
\hline 3 & 1951 & $\begin{array}{l}\text { SGHA } 4 \text { tahun } \\
\text { PGA } 5 \text { tahun }\end{array}$ & $\begin{array}{l}\text { Penetapan Menteri Agama } \\
\text { Nomor } 7 / 1951\end{array}$ \\
\hline 4 & 1953 & $\begin{array}{l}\text { PGA } 6 \text { tahun: } \\
\text { - } \quad \text { PGAPN } 4 \text { tahun } \\
\text { - } \quad \text { PGAAN } \\
\text { tahun }\end{array}$ & $\begin{array}{l}\text { Penetapan Menteri } \\
\text { Nomor 35/1953 }\end{array}$ \\
\hline 5 & 1959 & $\begin{array}{l}\text { PGAN } 4 \text { tahun } \\
\text { PGAN } 6 \text { tahun }\end{array}$ & $\begin{array}{l}\text { Penetapan Menteri } \\
\text { Nomor } 18 / 1959\end{array}$ \\
\hline 6 & 1978 & PGAN 3 tahun & $\begin{array}{l}\text { Keputusan Menteri } \\
\text { Nomor } 19 / 1978\end{array}$ \\
\hline 7 & 1992 & $\begin{array}{l}\text { PGAN menjadi } \\
\text { MAN }\end{array}$ & $\begin{array}{l}\text { Keputusan Menteri } \\
\text { Nomor 42/1992 }\end{array}$ \\
\hline
\end{tabular}

\section{F. Orientasi Kebijakan Kementerian Agama setelah "Rencana Sigit" dan "Rencana Arifin"}

Perubahan dari konsep sigit ke konsep Arifin tidak bisa dipandang sederhana. Keduanya mewakili dua kecenderungan besar dalam upaya pengembangan pendidikan Islam. Guru dalam pandangan kedua tokoh ini merupakan sosok yang berpengaruh besar untuk mengembangkan potensi murid dan memperbaiki citra lembaga pendidikan Islam. Untuk itu, keduanya memiliki komitmen yang sama 
dalam menyiapkan guru ideal. Hanya konsep guru ideal bagi keduanya agak berbeda. Abdullah Sigit, lebih cenderung mengimpikan guru-guru modern yang berwawasan Islam. Untuk melahirkan tipe guru demikian, porsi pengajaran umum di sekolah guru agama setidak-tidaknya sama dengan sekolah-sekolah di lingkungan kementeria Pendidikan. Sementara Arifin Temyang lebih menginginkan agar guru yang dihasilkan Kementerian Agama, memiliki kemampuan seimbang antara pengetahuan agama dan umum.

Kendati kedua tokoh tersebut telah tiada, konsep pendidikan yang di gagas keduanya tetap menarik untuk didiskusikan, terutama untuk membaca kecenderungan pengembangan pendidikan Islam akhir-akhir ini, konsep madrasah yang lebih menekankan pada materi agama (Seperti MAPK/ Madrasah Aliyah Program Khusus dan Madrasah Aliyah Keagamaan) lebih mewakili konsep Arifin.

Selain perubahan nama/bentuk lembaga dan masa belajar, yang menonjol dari perkembangan institusi pendidikan guru agama adalah pergeseran orientasi Kementerian Agama dalam pengadaan guru agama, dari pertimbangan kualitas ke kuantitas. Kebijakan pendidikan guru yang mengedepankan kualitas terjadi terutama selama ikatan dinas (19501969). Dimasa itu, jumlah lembaga pendidikan guru dirancang sesuai kebutuhan. Calon siswanya diseleksi ketat dan berikatan dinas. Mereka harus tinggal di asrama selama pendidikan (dengan biaya negara) agar kepribadian calon guru dapat dibina secara intensif. Mereka lalu diangkat sebagai PNS dengan gaji cukup tinggi setelah lulus. Dengan pola ini status sosial gutu cukup tinggi di masyarakat, sehingga menjadi guru merupakan pilihan utama yang membanggakan. Tidak heran jika pelajar terpandai berlomba masuk pendidikan guru.

Pemerintah orde lama sangat memperhatikan pendidikan guru. Hal ini didasari suatu paradigma bahwa guru haruslah menjadi fokus pendorong proses belajar murid. Karena itu, hanya calon yang memiliki kemampuan intelektual tinggi dengan disiplin dan karakter kepribadian yang baik yang bisa menjadi guru. Tidak salah jika pengembangan intensif lembaga pendidikan agama, utamanya di masa Orde Lama, merupakan salah satu prestasi menonjol Kementerian Agama dalam bidang pendidikan. 
Perhatian pemerintah yang tinggi terhadap pendidikan guru di masa-masa awal kemerdekaan juga tidak terlepas dari pengaruh pendidikan guru yang dikembangkan kolonial Belanda. Pola pendidikan guru di masa Hindia Belanda cukup ideal. Calan siswa diseleksi ketat, bagi yang lulus disediakan beasiswa dan harus tinggal diasrama agar dapat dilakukan pembinaan kepribadian guru secara instens, dan setelah lulus diangkat dengan gaji tinggi.

Perhatian pada kualitas mulai menurun setelah ikatan dinas dihapus karena keterbatasan anggaran, yang diiringi dengan semakin rendahnya gaji guru. Sejak itu, wibawa guru di mata masyarakat tidak menjadikan lembaga pendidikan guru sebagai pilihan utama, apalagi dengan mulainya terbukanya pekerjaan lain yang lebih menjanjikan. Sejak itu pula, calon siswa dilembaga pendidikan guru tidak lagi berasal dari lulusan terbaik disekolahnya.

Kondisi di atas sepertinya berbeda dengan kondisi saat ini, profesi guru telah lama menjadi hal yang tidak prestisius bagi masyarakat Indonesia. Dengan rendahnya gaji bagi para guru, sehingga lulusan terbaik dari sekolah lebih memilih profesi yang menjanjikan. Meskipun pemerintah berusaha dengan sekuat tenaga untuk meningkatkan kualitas pendidikan di Indonesia dengan memberikan tunjangan profesi yang tinggi. Tapi hasilnya masih belum dirasakan masyarakat. Diperlukan keberanian dan kebijakan baru untuk membenahi sistem pendidikan di Indonesia yang diawali dengan pembenahan lembaga pendidikan dan tenaga kependidikan (LPTK) yang ada.

\section{G. Kesimpulan}

Politik pendidikan guru agama Islam pada masa Orde lama tidak dapat dilepaskan dari perjuangan memasukkan materi agama di sekolah. Sudah sejak lama Pemerintah Belanda menjadikan pendidikan agama terpisah dari pendidikan sekolah, dengan asumsi pendidikan sekolah itu netral dari pendidikan agama. Pendidikan agama menjadi urusan pribadi masing-masing dan bukan menjadi bagian integral pada pendidikan sekolah. Pemisahan ini menjadikan perbedaan yang sengit antara kaum nasionalis dan umat Islam dalam memandang pendidikan agama. 
Kaum nasionalis memiliki kecenderungan sinis dan apatis terhadap kaum muslim. Demikian juga kaum muslim berusaha untuk menyelamatkan kepentingannya dalam kancah politik di Indonesia sebagai mayoritas. Tetapi menjadi hal yang menarik untuk dikaji adalah meskipun Kementerian agama lahir belakangan tetapi usaha yang dilakukan pasca kemerdekaan harus diakui sebagai upaya yang luar biasa dalam menyediakan pendidikan yang berkualitas bagi umat Islam, terbukti dengan penyelenggaraan pendidikan guru yang pernah dijalankan. Upaya membangun kesejajaran dengan Kementerian Pendidikan dalam mengelola lembaga pendidikan menjadi hal yang tidak dapat dielakkan.

\section{DAFTAR PUSTAKA}

Azyumardi Azra, HM Rasjidi BA Pembentukan Kementerian Agama dalam Revolusi, dalam Azyumardi Azra dan Saiful Umam, ed. Menterimenteri Agama RI Biografi Sosial Politik,(Jakarta:INIS,1998).

Amal Bakti Departemen Agama RI 3 Januari 1946-3 Januari 1996 (50 Tahun Departemen Agama); Eksistensi \& Derap Langkahnya (Jakarta: Departemen Agama RI, 1996)

Almanak 1974 (Jakarta: Direktorat Pendidikan Agama Dirjen Bimas Islam Departemen Agama,t.th), 72, Rahim, Arah Baru Pendidikan Islam.

Arief Subhan, Lembaga Pendidikan Islam Indonesia Abad ke-20 Pergumulan antara Modernisasi dan Identitas"(Jakarta: Kencana,2012)

B.J. Boland, The Struggel of Islam in Modern Indonesia,(The Hague: Martinus Nijhoff,1997)

Bachtiar Effendy,Islam dan Negara: Transformasi Pemikiran dan Praktik Politik Islam di Indonesia (Jakarta: Paramadina, 1998).

D.P. Sati Alimin (ed). Almanak Djawatan Pendidikan Agama 1959, (Jakarta: N.Vperdana, 1959).

Husni Rahim, Madrasah dalam Politik Pendidikan di Indonesia, (Jakarta: Logos,2005).

Karel A. Steenbrink,Pesantren Madrasah Sekolah;Pendidikan Islam dalam Kurun Moderen (Jakarta: LP3ES). 
K.H. Imam Zarkasyi, Peletak Modernisasi Pendidikan Pesantren, Madrasah; Jurnal Komunikasi Dunia Perguruan Tinggi (No.03/I/April-Juni 1997).

Lambert Kelabora,Assumption Underlaying Religious Instruction”.

Mujahid AK dan Achmad Syahid,ed. Memelihara Tradisi Merayakan Inovasi 25 Tahun Puslitbang Pendidikan Agama dan Keagamaan (Jakarta: Badan Litbang Agama dan Diklat Keagamaan Departemen Agama RI, 2003)

Marwan Saridjo, Bunga Rampai Pendidikan Agama Islam (Jakarta: Amisco,1996), 56; dan Haidar Putra Daulay, Historisitas dan Eksistensi Pesantern Sekolah dan Madrasah (Yogyakarta: Tiara Wacana, 2001).

Muljanto Sumardi, Sejarah Singkat Pendidikan Islam di Indonesia 19451975 (Jakarta:Lembaga Penelitian Ilmu Agama),dan Kemasyarakatan (LPIAK)-Badan Penelitian dan Pengembangan Agama Departemen Agama,1977).

Mahmud Yunus, Sejarah Pendidikan Islam (Jakarta:Mutiara,1992).

Muhammad Kosim, Pendidikan Guru Agama di Indonesia Pergumulan dan Problema Kebijakan 1948-2011 (Pustaka Nusantara, 2012).

Peraturan Bersama bernomor Menteri Agama No.K/I/9180 tanggal 16 Juli 1951 dan Meneteri Pendidikan No. 17678/Kab. Tanggal 16 Juli 1951.

Sirozi, Politik Pendidikan Dinamika Hubungan antara Kepentingan Kekuasaan dan Praktik Penyelenggaaraan Pendidikan (Jakarta: Raja Grafindo Persada, 2010)

Soegarda Poerbakawatja, Pendidikan dalam Alam Indonesia Merdeka (Jakarta: Gunung Agung,1970).

Zaini Ahmad Syis, Inventarisasi dan Pengefektifan Out put PGAN sehubungan dengan Pengadaan Guru Agama Tingkat Dasar”, dalam laporan Lokakarya Out put PGAN bagi Angkatan Kerja (Jakarta: Pusat Penelitian dan Pengembangan Pendidikan Agama Badan Litbang Departemen Agama,1978/1979). 